\title{
Mendeteksi Keakuratan Metode Noise Salt and Pepper dengan Median Filter
}

\author{
Nurul Fadillah¹, Chicha Rizka Gunawan² \\ ${ }^{1}$ Universitas Samudra, Aceh \\ e-mail: nurulf479@gmail.com \\ ${ }^{2}$ Universitas Samudra, Aceh \\ e-mail: chicharizka66@gmail.com
}

\begin{abstract}
Abstrak
Suatu data atau informasi disajikan tidak hanya berupa data teks tetapi juga dapat berupa audio, video, dan gambar. Pada zaman sekarang, informasi sangatlah penting dan diperlukan, begitu juga informasi yang terdapat pada citra. Citra (image) atau istilah lain untuk gambar merupakan salah satu komponen multimedia yang berperan penting sebagai bentuk informasi visual. Dibandingkan dengan data teks, citra memiliki banyak informasi. Namun terkadang citra juga dapat mengalami penurunan yaitu degradasi atau penurunan kualitas yang disebabkan oleh derau / noise, warna terlalu kontras, kabur, dan lain-lain. Ada beberapa jenis noise dalam pengolahan citra salah satunya yaitu salt \& pepper noise. Noise salt \& pepper berbentuk seperti bintik hitam dan putih pada citra. Untuk mengurangi noise dibutuhkan suatu metode, salah satunya yaitu median filter. Pada makalah ini, citra yang bernoise salt and pepper, setelah direduksi menggunakan median filter, gambar yang bernoise tersebut langsung menjadi sebuah citra yang bersih yaitu citra yang dihasilkan sesuai dengan gambar aslinya.
\end{abstract}

Kata Kunci : Noise, salt and pepper, filtering, metode median filter

\section{Abstract}

A data or information is presented not only in the form of text data but also can be in the form of audio, video, and images. Nowadays, information is very important and necessary, as is information contained in the image. Image (image) or other terms for images is one of the multimedia components that play an important role as a form of visual information. Compared to text data, images have a lot of information. But sometimes images can also experience a decrease, namely degradation or deterioration in quality caused by noise / noise, too contrasting colors, blurring, and others. There are several types of noise in image processing, one of which is salt \& pepper noise. Noise salt \& pepper are shaped like black and white spots on the image. To reduce noise, a method is needed, one of which is the median filter. In this paper, the image that behaves salt and pepper, after being reduced using the median filter, the image that sounds is immediately a clean image, that is, the image produced in accordance with the original image.

\section{Keywords: noise, salt and pepper, filtering, median filter method}

\section{Pendahuluan}

Suatu data atau informasi disajikan tidak hanya berupa data teks tetapi juga dapat berupa audio, video, dan gambar. Pada zaman sekarang informasi sangatlah penting dan diperlukan, begitu juga informasi yang terdapat pada citra (A. Fitri, 2010). Citra (image) atau istilah lain untuk gambar merupakan salah satu komponen multimedia yangberperan penting sebagai bentuk informasi visual (Syarifuddin, 2012).
Dibandingkan dengan data teks citra memiliki banyak informasi daripada data teks. Namun terkadang citra juga dapat mengalami penurunan degradasi atau penurunan mutu yang disebabkan oleh derau / noise, warna terlalu kontras, kabur, dan lain-lain (S.N Syarifuddin, 2012). Gambar atau piksel yang mengurangi kualitas citra dalam pengolahan citra disebut derau (noise). Dilihat dari karakteristik dan bentuknya noise pada citra dibagi menjadi 
beberapa macam yaitu Gaussian noise, speckle noise, salt and pepper noise, Poison noise (H. Rasyidah, 2011). Untuk meningkatkan kualitas citra dan mengurangi noise agar informasi yang ada pada citra dapat dipahami dengan baik dibutuhkan metode filtering.

Dalam penelitian lain yang dilakukan oleh (S.N Syarifuddin, 2012) menjelaskan tentang "Analisis filtering citra metode mean filter dan median filter, menggunakan noise gaussian dan salt and pepper. Pada penelitian tersebut digunakan besaran MSE dan PSNR untuk membandingkan pixelpexel pada posisi yang sama dari dua citra yang berlainan. Dari hasil penelitian dapat disimpulkan bahwa untuk perbaikan citra dengan noise berupa Gaussian noise lebih baik dilakukan dengan metode mean filter, sedangkan untuk noise salt and pepper menggunakan metode median filter."

Dari penelitian di atas dapat disimpulkan bahwa metode yang baik dalam reduksi noise salt and pepper adalah median filter dan belum ada penelitian yang membahas tentang mendeteksi keakuratan metode median filter tersebut, sehingga muncul suatu ide untuk membuat penelitian tentang mendeteksi keakuratan noise salt and pepper dengan menggunakan metode median filter.

Mengacu pada latar belakang, maka dapat dirumuskan permasalahan penelitian bagaimana hasil penerapan median filter. Dan metode median filter lah yang paling akurat dalam reduksi noise salt and pepper. Jadi tujuan penelitian adalah untuk mengetahui bahwa metode median filter adalah metode yang akurat dalam mereduksi noise salt and pepper. Dari hasil penelitian, diperoleh bahwa citra bernoise (salt and pepper) yang menggunakan median filter menjadi sangat bersih.

\section{Metode Penelitian}

\subsection{Teknik Analisis Data}

Setelah data didapatkan, selanjutnya adalah menguraikan cara pengolahan data secara konkrit. Ada beberapa tahapan yang dilakukan terhadap data-data yang diperoleh. Tahapan-tahapan tersebut antara lain :

1. Merubah citra berwarna menjadi grayscale.
2. Menambahkan noise salt and pepper pada citra grayscale sesuai intensitas yang diinginkan

3. Menerapkan metode median filter untuk proses pengurangan noise salt and pepper.

\subsection{Metode yang Diusulkan}

Metode yang digunakan dalam penelitian ini adalah median filter. Untuk lebih jelasnya dapat dilihat pada penjelasan dibawah ini.

\subsubsection{Median Filter}

Metode median filter merupakan filter non linear yang dikembangkan oleh Tukey. Metode tersebut berfungsi mengurangi noise dan menghaluskan citra. Dikatakan non linear karena cara kerja penapis ini tidak termasuk kedalam kategori operasi konvolusi. Operasi nonlinear dhitung dengan cara mengurutkan nilai intensitas sekelompok pixel, kemudian mengganti nilai pixel yang diproses dengan nilai tertentu.

Pada median filter suatu window atau penapis yang memuat sejumlah pixel ganjil digeser titik per titik pada seluruh daerah citra. Lalu nilai-nilai tersebut diurutkan secara ascending untuk kemudian dihitung nilai mediannya. Nilai median tersebut akan menggantikan nilai yang berada pada pusat bidang window [2]. Dari beberapa penelitian metode ini sangat cocok untuk reduksi noise sal \& pepper. Contoh filtering dengan filter $3 \times 3$ sebagai berikut

Tabel 1. Filtering $3 \times 3$

\begin{tabular}{|l|l|l|l|l|l|l|}
\hline & & & & & & \\
\hline & 123 & 125 & 126 & 130 & 140 & \\
\hline & 122 & $\mathbf{1 2 4}$ & $\mathbf{1 2 6}$ & $\mathbf{1 2 7}$ & 135 & \\
\hline & 118 & $\mathbf{1 2 0}$ & $\mathbf{1 5 0}$ & $\mathbf{1 2 5}$ & 134 & \\
\hline & 119 & $\mathbf{1 1 5}$ & $\mathbf{1 1 9}$ & $\mathbf{1 2 3}$ & 133 & \\
\hline & 111 & 116 & 110 & 120 & 130 & \\
\hline & & & & & & \\
\hline
\end{tabular}

Dengan menggunakan citra diatas, diambil $3 \times 3$ filtering. Nilai masing-masing piksel yang bertetanggaan setelah diurut- 
kan adalah sebagai berikut : $115,119,120$, $123,124,125,126,127,150$. Hasil pengurutan tersebut mendapatkan nilai median 124. Nilai median ini digunakan untuk menggantikan nilai pusat mask, sehingga nilai 150 akan diganti dengan 124 . Berikut adalah metode yang diusulkan secara keluruhan.

Berdasarkan tabel 1, terdapat beberapa tahapan proses, antara lain :

a. Proses pra pengolahan. Pada tahap ini dilakukan penambahan noise secara manual, lebih tepatnya tingkat intensitas noise.

b. Tahap pengolahan. Pada tahap ini dilakukan proses pengolahan lebih lanjut pada citra yang telah didapatkan dari tahap pra pengolahan. Pada tahap ini citra yang bernoise di filter dengan menggunakan metode median filter, dan setelah itu menjadi data keluaran.

c. Tahap analisis. Pada tahap ini, citra di analisis secara sederhana. Citra yang dibandingkan ada 3 yaitu, citra asli atau citra tidak bernoise, citra yang telah difilter.

\subsubsection{MSE dan PSNR}

Pada pengolahan citra digital mempunyai standar pengukuran galat (error) kualitas citra yaitu MSE dan PSNR [6]. MSE dan PSNR digunakan untuk mengukur kualias citra.

Peak Signal to Noise Ratio (PSNR) digunakan untuk mengukur tingkat keberhasilan dan performa dari suatu metode filtering pada citra. Pengukuran teknik visual setiap orang berbeda beda, jadi lebih baik menggunakan PSNR dan MSE untuk pengukuran performa yang baik.

PSNR (Peak Signal to Noise Ratio) adalah perhitungan yang menentukan nilai dari sebuah citra. Besar kecilnya nilai MSE yang terjadi pada citra mempengaruhi nilai PSNR. PSNR biasanya dinyatakan dalam skala decibel $(\mathrm{dB})$ dalam bentuk logaritma. Semakin kecil nilai PSNR, hasil yang diperoleh semakin jelek. Sebaliknya semakin besar nilai PSNR, hasil yang diperoleh semakin baik. Jadi hubungan antara nilai MSE dan PSNR adalah semakin kecil nilai PSNR, maka semakin besar pula nilai MSE -nya. Untuk mengukur kualitas pada penyusunan ulang citra digunakan PSNR .

MSE (Mean Square Error) adalah nilai error kuadrat rata rata antar hasil citra asli dengan citra manipulasi. Nilai MSE diperoleh dengan cara membandingkan nilai citra hasil pada posisi pixel yang sama dengan selisih pixel pixel citra asal.

Misal Sxy adalah citra masukan Cxy adalah citra keluaran, kedua citra tersebut mempunyai $\mathrm{M}$ baris dan $\mathrm{N}$ kolom, maka dapat didefinisikan sebagai berikut :

$$
M S E=\frac{1}{M N} \sum_{x=1}^{M} \sum_{y=1}^{N}\left(S_{x y}-C_{x y}\right)^{2}
$$

Rumus menghitung PSNR adalah :

$$
\begin{aligned}
P S N R= & 10 \cdot \log _{10}\left(\frac{M A X_{1}^{2}}{M S E}\right) \\
& =10 \cdot \log _{10}\left(\frac{M A X_{1}}{\sqrt{M S E}}\right) \\
& =20 \cdot \log _{10}\left(M A X_{1}\right)-10 \cdot \log _{10}(M S E)
\end{aligned}
$$

Nilai PSNR dibawah 30dB mengindikasikan kualitas yang relative rendah, dimana distorsi yang dikarenakan penyisipan terlihat jelas. Akan tetapi kualitas stego-image yang tinggi berada pada nilai $40 \mathrm{~dB}$ dan diatasnya. Berikut ini adalah contoh perhitungannya. citra awal adalah citra yang memiliki noise, dan citra akhir adalah citra yang sudah di filter.

Tabel 2. Hasil perhitungan citra awal dan citra akhir

\begin{tabular}{|l|l|l|}
\hline 7 & 1 & 1 \\
\hline 2 & 3 & 4 \\
\hline 5 & 0 & 6 \\
\hline \multicolumn{3}{|c|}{ Citra awal }
\end{tabular}




\begin{tabular}{|l|l|l|}
\hline 6 & 1 & 1 \\
\hline 3 & 3 & 3 \\
\hline 5 & 3 & 6 \\
\hline
\end{tabular}

Citra akhir

$$
M S E=\frac{\begin{array}{c}
(7-6)^{2}+(1-1)^{2}+(1-1)^{2}+(2-3)^{2}+(3-3)^{2} \\
+(4-3)^{2}+(5-5)^{2}+(0-3)^{2}+(6-6)^{2}
\end{array}}{3 \times 3}
$$

$M S E=\frac{1+0+0+1+0+1+0+9+0}{9}=1,33$

$$
\mathrm{PSNR}=20 \log _{10}\left(\frac{7}{\sqrt{1,33}}\right)=15,665
$$

\section{Hasil dan Pembahasan}

Pada penelitian ini dilakukan pengujian untuk mengetahui efektivitas metode median filter pada noise salt \& pepper. Tampilan berikut ini adalah screenshot dari hasil pengujian reduksi noise salt \& pepper :

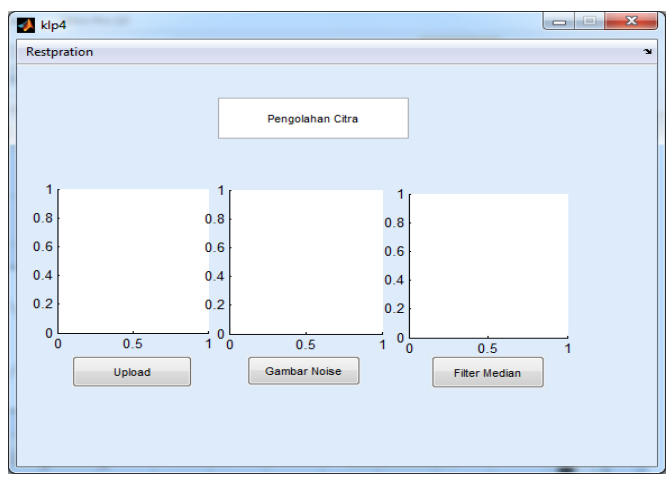

Gambar 1. Tampilan Awal

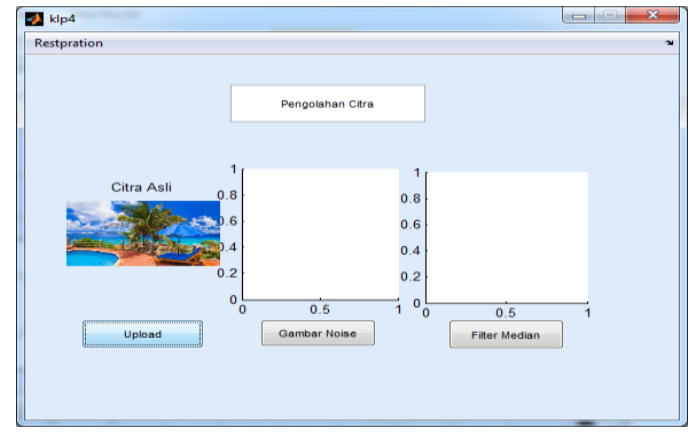

Gambar 2. Citra Asli

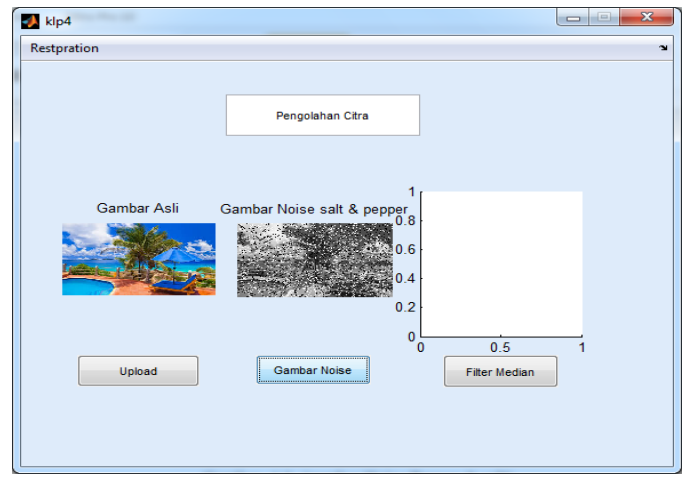

Gambar 3. Citra noise salt and pepper

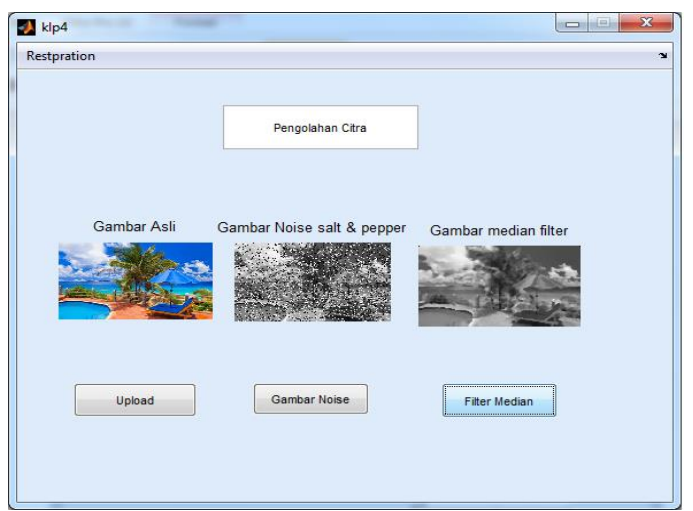

Gambar 4. Citra hasil median filter

\section{Kesimpulan}

Dari hasil penelitian dapat disimpulkan antara lain sebagai berikut :

a. Noise salt and pepper adalah bentuk noise yang biasanya terlihat titik-titik hitam dan putih seperti tebaran garam dan merica

b. Noise salt and pepper disebabkan karena terjadinya error bit dalam pengiriman data pixel-pixel

c. Metode median filter sangat baik untuk menghilangkan noise salt and pepper karena pada hasil menunjukkan gambar yang telah ditambah noise menjadi sangat bersih.

\section{Referensi}

A. Fitri, 2010, Perbandingan Metode LowPass Filter dan Median Filter dalam Penghalusan Citra (Image Smoothing) Untuk Peningkatan Kualitas Citra (Image 
Enhancement). Skripsi Teknik Informatika Universitas Komputer Indonesia, Bandung.

B. H. Sholihin, Ricky Aprias; Purwoto, 2014, Perbaikan Citra dengan Menggunakan Median Filter dan Metode Histogram Equalization. vol. 14, no. 02. Skripsi Teknik Elektro Uiversitas Muhammadiyah Surakarta, Surakarta.

E. Listiyani, 2013, Implementasi Adaptive Median Filter sebagai Reduksi Noise Pada Citra Digital. Skripsi Teknik Informatika Sekolah Tinggi Manajemen

H. Rasyidah, 2011, Analisis Pengaruh Noise Terhadap Deteksi Wajah Manusia Pada Citra Berwarna Menggunakan Fuzzy.
Skripsi Teknologi Informasi Politeknik Negeri Padang, Padang.

M. K. Wardhani, Rika Novita; Delimayanti, 2013, Analisis Penerapan Metode Konvolusi Untuk Reduksi Derau Pada Citra Digital. Skripsi Teknik Informatika Politeknik Negeri Jakarta, Jakarta, pp. 191-198.

S. N. Syarifuddin, 2012, Analisis Filtering Citra dengan Metode Mean Filter dan Median Filter. Skripsi Teknik Informatika Universitas Komputer Indonesia, Bandung. 